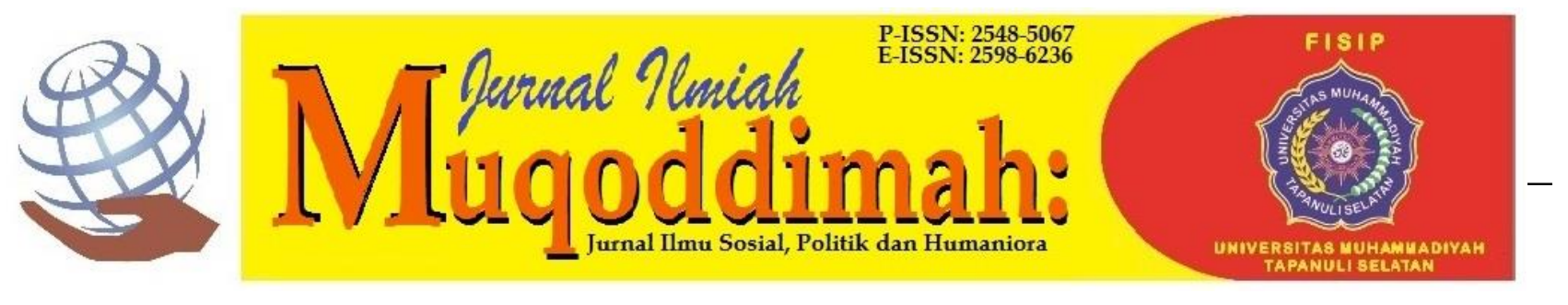

\title{
Organisasi Kriminal Transnasional: Perburuan Gajah dan Perdagangan Gading llegal di Republik Demokratik Kongo (DRC)
}

\author{
Sahlawati1), Katong Ragawi Numadi2) \\ Fakultas IImu Sosial dan IImu Politik, Universitas Airlangga \\ Jalan Dharmawangsa Dalam, Surabaya, Jawa Timur, Indonesia \\ Sahlawati-2019@fisip.unair.ac.id') \\ Katong.ragawi.numadi-2019@fisip.unair.ac.id²)
}

\begin{abstract}
Abstrak
Ancaman isu kontemporer jarang memperoleh perhatian internasional salah satunya tentang illicit trade yang digolongkan sebagai Transnational Organized Crime (TOC). Illicit Trade berlangsung lintas negara dan dilakukan secara ilegal. Perdagangan satwa langka merupakan salah satu bentuk illicit trade yang marak dilakukan terutama di kawasan negara berkembang di Afrika, Asia, dan Amerika Latin. Kawasan sentral Afrika termasuk Republik Demokratik Kongo (DRC) merupakan negara yang terbilang rentan terhadap aktivitas organisasi kriminal transnasional terutama dalam aspek penyelundupan satwa. Penelitian ini bertujuan untuk memaparkan permasalahan kontemporer yang jarang mendapat perhatian dari elemen global. Untuk mendapatkan data tentang pemburuan dan perdagagan gading illegal maka digunakan metode kualitatif yang bersumber dari data sekunder seperti buku, jurnal, dan artikel daring. Hasil menunjukkan bahwa masalah illicit trade mulai mendapatkan perhatian pemerintah dan masyarakat global memasuki tahun 2010-an. Respon yang dilakukan dengan memperbaiki aturan dan langkah strategis terhadap pemburu dan produsen gading illegal dengan melibatkankan seluruh elemen diantaranya Republik Demokratik Kongo, organisasi regional dan internasional, organisasi internasional non-pemerintah, dan peran dari masyarakat lokal.
\end{abstract}

Kata Kunci: Gading ilegal, organisasi criminal transnasional, Perdagangan gelap, Republik Demokratik Kongo.

\begin{abstract}
The threat of contemporary issues rarely gets international attention. One of them is illicit trade, classified as Transnational Organized Crime (TOC). Illicit Trade takes place across countries and is carried out illegally. The trade in endangered species is a form of illicit trade, especially in developing countries in Africa, Asia, and Latin America. Central Africa including the Democratic Republic of the Congo (DRC) is a country that is relatively vulnerable to the activities of transnational criminal organizations, especially in the aspect of animal smuggling. This study aims to describe contemporary problems that rarely get attention from global elements. To obtain data on the poaching and illegal ivory trade, qualitative methods are used which are sourced from secondary data such as books, journals, and online articles. The results show that illicit trade issues began to get the attention of the government and the global community entering the 2010s. The response was carried out by improving regulations and strategic steps against illegal ivory hunters and producers by involving all elements including the Democratic Republic of the Congo, regional and international organizations, international non-governmental organizations, and the role of local communities.
\end{abstract}

Keywords: Illegal ivory, transnational criminal organizations, illicit trade, Democratic Republic of the Congo. 


\section{PENDAHULUAN}

Neoberalisasi ekonomi merupakan salah satu fitur utama era global saat ini. Berbagai aktivitas perdagangan antar wilayah dilakukan melibatkan berbagai komoditas barang dan jasa yang mana negara bersama korporasi sebagai aktor utama. Situasi ini menawarkan kemudahan sekaligus peluang bagi masyarakat global terhadap akses ekonomi, namun disisi lain juga menimbulkan dimensi ancaman baru yang lahir sebagai konsekuensi borderless economy. Salah satu isu ancaman kontemporer yang justru jarang mendapatkan perhatian internasional adalah mengenai illicit trade yang tergolongkan sebagai transnational organized crime (TOC). Seperti halnya proses perdagangan biasa, dewasa ini illicit trade berlangsung lintas negara yang mana produsen, distributor, dan konsumennya berada di berbagai wilayah negara yang berbeda. Akan tetapi berbeda dengan perdagangan umum yang dilakukan melalui prosedur legal, illicit trade justru dilakukan secara illegal serta melibatkan pelanggaran terhadap aturan yang berlaku. Komoditas yang diperdagangkan juga merupakan barang dan jasa yang dilarang untuk dijual biasanya berupa barang berbahaya, barang langka, bahkan manusia (Felbab-Brown, 2009). Selain itu semua proses yang dilakukan melibatkan aktor yang tidak terlegitimasi yang biasanya terafiliasi dengan kelompok kejahatan tertentu. Perdagangan satwa langka merupakan salah satu bentuk illicit trade yang marak dilakukan terutama di kawasan negara berkembang di Afrika, Asia, dan Amerika Latin. Globalisasi mengakibatkan aktivitas perdagangan ini semakin masif terjadi, yang mana menurut data Transnational Alliance to Combat Illicit Trade (TRACIT), perdagangan satwa liar merupakan salah satu aktivitas kriminal transnasional yang dilakukan secara masif sehingga berdampak terhadap proyeksi global sustainable development. Tercatat dalam jangka waktu empat puluh tahun, dunia telah mengalami penurunan keanekaragaman satwa vertebrata mencapai $58 \%$ dan perdagangan satwa illegal merupakan penyebab terbesar kedua dibalik ancaman penurunan tersebut. Peningkatan ini dapat dibuktikan dengan tingginya jumlah peristiwa perdagangan hewan liar yang terdeteksi berdasarkan data World Wildlife Seizures (World WISE) terdapat 132 ribu upaya perdagangan yang tertangkap di 120 negara dalam jangka waktu tahun 2005 hingga tahun 2014. Secara keseluruhan data di bawah (Tabel 1.1) menunjukan peristiwa penangkapan aktivitas perdagangan teridentifikasi hampir di seluruh wilayah terutama Cina, Amerika Utara, dan Eropa yang dianggap sebagai negara tujuan dengan estimasi mencapai 62 ribu peristiwa penangkapan. Penangkapan tersebut juga membuktikan bahwa perdagangan illegal ini melibatkan beragam spesies langka mulai dari mamalia, ungags, reptil, hingga satwa laut.

\section{Tabel 1.1}

Peta Aktivitas Global Illicit Trade

Map 1 Total number of seizures reported by country, 2004-2015

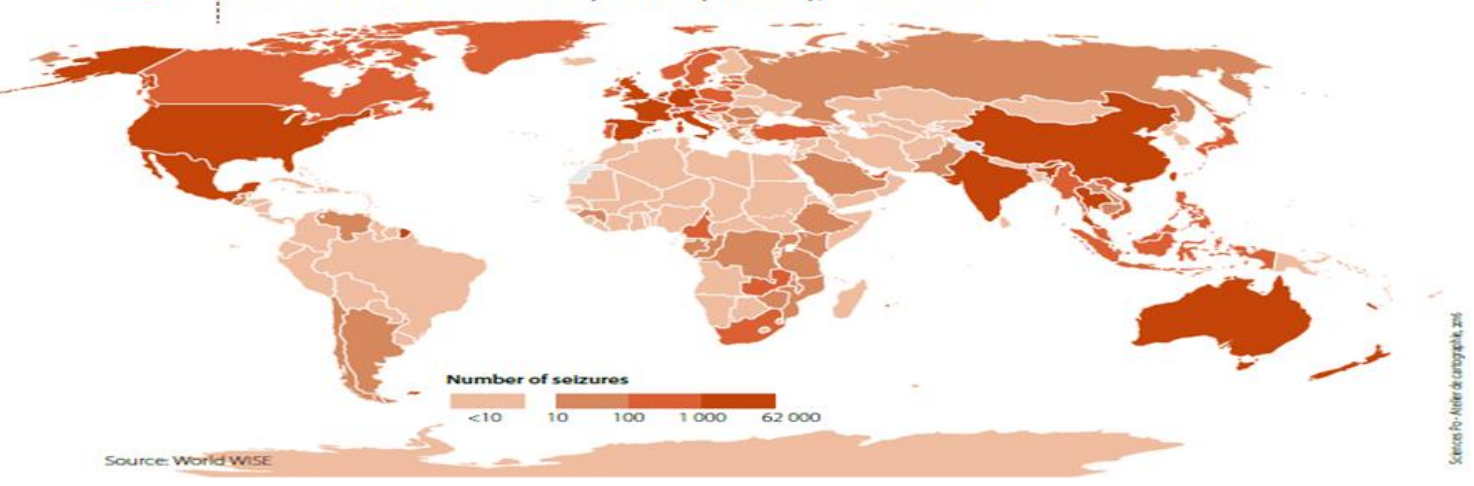

Sumber: www.unodc.org

Dilihat dari sektor negara produsen, tidak adanya kesadaran pemerintah diikuti dengan minimnya perlindungan hukum menjadikan kelompok kriminal pemburu satwa langka leluasa dalam mengksploitasi hewan langka bernilai tinggi serta memperdagangkan baik lokal maupun transnasional menuju konsumen terutama di negara-negara perekonomian maju. Situasi ini kerap terjadi di Afrika terutama di sub-kawasan Afrika Tengah sebagai salah satu sumber komoditas satwa langka yang diperdagangkan secara illegal terutama jenis gajah Afrika. Berdasarkan data diatas (Tabel 1.1) dapat dilihat gajah merupakan jenis satwa paling 
banyak diperdagangkan dengan persentase $18 \%$ dari total wildlife trade pada tahun 2005 sampai 2014. Sementara jumlah lebih dari 26 ribu kg gading gajah telah diperjual belikan sejak tahun 2007 hingga tahun 2015. Salah satu negara di kawasan yang menghadapi permasalahan wildlife crime termasuk wildlife trade relatif tinggi terutama terhadap jenis gajah adalah Republik Demokratik Kongo (DRC). Sebagai salah satu pusat keragaman hewan terutama gajah, enam taman nasional di DRC sering kali digunakan oleh kelompok kriminal sebagai lahan perburuan gajah terutama untuk dimanfaatkan gadingnya sebagai komoditas perdagangan illegal yang bernilai tinggi. Salah satu peristiwa terjadi pada Februari tahun 2018 ketika otoritas DRC menangkap sindikat kelompok kriminal yang memperdagangkan lebih dari $30 \mathrm{~kg}$ gading dan produk ornamen dari gading. Bukti lain terlihat dari penangkapan sindikat perdagangan gading oleh Singapura dengan nilai 13 juta USD dengan jumlah total mencapai 8,8 ton gading yang berasal dari DRC (African News, 2019). Selain itu DRC juga terkenal sebagai negara pusat perdagangan gading gajah yang mana tercatat pada tahun $2015,68 \%$ pasar produk gading gajah terutama berasal dari wilayah Kinshasa.

Kawasan sentral Afrika termasuk DRC merupakan negara yang terbilang rentan terhadap aktivitas organisasi kriminal terutama dalam aspek penyelundupan satwa. Kombinasi antara minimnya kesadaran masyarakat disertai dengan lemahnya tata kelola pemerintah mengakibatkan persoalan perdagangan illegal semacam ini sulit diatasi oleh negara seperti DRC. Berdasarkan data United Nation Environment Programme (UNEP) memperkirakan setiap tahunnya sumber daya alam termasuk gading di DRC tereksploitasi secara ilegal hingga bernilai 0,7-1,3 Miliar USD yang mana 10-30\% keuntungan atau 426 juta USD diantaranya mengalir kepada kelompok kriminal transnasional yang berbasis di luar wilayah DRC bagian. Sementara itu sebagian besar keuntungan mencapai $98 \%$ mengalir bagi kelompok transnasional diluar negara DRC. Melihat besarnya kerugian serta dampak terhadap perkembangan lingkungan, perdagangan satwa illegal di DRC menjadi suatu permasalahan yang membutuhkan urgensi penanganan global. Sejauh ini langkah penanganan dapat dipahami dalam dua arah yang saling terkait yaitu secara domestik melalui respon Pemerintah DRC. Upaya pemerintah ini salah satunya dapat dilihat pada tahun 2011 ketika Perdana Menteri DRC Adolphe Muzito menandatangani Deklrasi Kinshasa yang merujuk pada perlindungan kawasan konservasi termasuk keanekaragaman satwa di enam kawasan konservasi. Deklarasi dibarengi dengan pengembangan langkah perlindungan strategis yang dilakukan ICCN sebagai otoritas satwa liar di DRC (UNESCO Media Services, 2017). Melihat bahwa kejahatan perdagangan satwa di DRC bersifat transnasional, terdapat perhatian internasional secara sinergis dengan upaya pemerintah melibatkan pemerintah negara lain serta organisasi internasional seperti AUC, UNDP, UNEP, UNODC, dan CITES. Disisi lain perhatian juga ditunjukan oleh organisasi konservasi lingkungan non-pemerintah seperti WWF.

Meraknya perdagangan gading ilegal disebabkan oleh resiko yang renda namun merupakan usaha dengan keuntungan yang tinggi. Kejahatan terhadap satwa liar menempati urutan ke empat setelah narkoba, senjata, dan perdagangan manusia (United Nations Office on Drugs and Crime, 2015). Penelitian yang relevan dengan topik dapat ditemukan pada "The Elephant Poaching Crisis in Tanzania: A Need to Reverse the Trend and the Way Forward" yang membahas bahwa perburuan gajah memiliki dampak secara ekonomi, politik, sosial, dan ekologi. Dampak tersebut antara lain konflik politik dan peningkatan ketidakamanan global, terkikisnya kredibilitas pemerintah secara internasional, penurunan populasi satwa yang menyebabkan pada kerentanan spesies terhadap kepunahan. Dari dampak tersebut mengakibatkan pendapatan pemerintah menjadi berkurang, dan dukungan lokal terhadap konservasi menjadi berkurang karena tidak ada keuntuntungan yang diperoleh. Maka melihat dampak dan akibat, maka muncul permintaan global supaya terdapat upaya untuk menghentikan perburuan gajah dan perdagangan gading ilegal (Kideghesho, 2016). Dalam tulisan "Use of Dichotomous Ivory Stockpile Management Strategies by African Elephant Range States: A Threat $t$ Effectively Combatting the Illegal Ivory Trade" penulis merekomendasika untuk memerangi perdagangan gading ilegal, maka diperlukan aksi kolektif yang besar mulai dari komunitas internasional, pemerintah, organisasi antar pemerintah, organisasi non-pemerintah, dan masyarakat lokal. Aksi kolektif ini penting arena perdagangan gelap dapat memberikan ancaman pada keamanan manusia dan pembangunan internasional 
(Brecht, 2016). Tulisan lainnya dapat ditemukan pada "Wildlife Trafficking: the illicit trade in wildlife, animal parts, and derivatives Illegaler Handel mit Tieren, Tierbestandteilen und Tierprodukten" yang menyatakan bahwa terdapat kesenjangan dalam rezim kontrol domestik dan internasional, kesulitan mengindentifikasi komoditas ilegal dan produk sekunder, rute perdagangan yang rumit membuat sulit untuk membatasi perdagangan gading gajah. Masalah tersebut masih sulit diatasi karena komitmen politik dan kapasitas operasional tidak sepadan dengan skala masalah (Ege et al., 2020). Kontribusi WWF secara spesifik lebih dijelaskan dalam tulisan "Conservation planning for a widespread, threatened species: WWF and the African elephant Loxodonta africana" bahwa kontribusi spesifik WWF yaitu konservasi gajah yang mempertimangkan faktor kelembagaan dan biologis. Fokus WWF mempertimbangkan faktor kelembafaan dan bilogis dalam bentuk konservasi dilatarbelakangi peluang untuk keberhasilan lebih tinggi (Stephenson \& Ntiamoa-Baidu, 2020). Urgensi tulisan ini terdapat pada pemaparan mendalam di Republik Demokratik Kongo dengan menyajikan secara jelas permasalahan pemburuan dan perdagangan gading ilegal dan memaparkan secara jelas keterlibatan setiap aktor-aktor yang dapat berperan pening dalam memerangi permasalahan illicit trade. Sehingga dengan adanya tulisan ini bertujuan untuk memaparkan permasalahan kontemporer yang jarang mendapat perhatian dari elemen global. Harapannya dapat memberikan kesadaran betapa pentingnya permasalah ini di era kontemporer.

\section{METODE}

Penelitian ini menggunakan metode kualitatif. Data didapatkan dari sumber sekunder yang berkaitan dengan pemburuan gajah dan perdagangan gading illegal. Sumber sekunder dapat diperoleh dari bahan-bahan bacaan diantaranya; buku, journal, dan artikel daring. Metode pengumpulan data dari sumber sekunder juga dapat disebut sebagai studi kepustakaan.

\section{HASIL DAN PEMBAHASAN \\ Transnational Organized Crime (TOC): Illicit Wildlife Trade}

Eksistensi organisasi kriminal transnasional merupakan konsekuensi negatif dibalik semakin derasnya gelombang globalisasi. Secara sederhana TOC dapat dipahami sebagai aktivitas kriminal atau ilegal yang dilakukan secara lintas batas negara dan regional yang melibatkan kelompok atau otoritas illegal tertentu. TOC merupakan kelompok kriminal yang secara rasional memperoleh keuntungan ekonomi dari aktivitas ilegal serta adanya permintaan dari pasar terhadap barang maupun jasa ilegal tersebut (Van Dijk \& Spapens, 2014). Aktivitas kriminal semacam ini pada era global mampu menjaga eksistensi bahkan mengalami peningkatan melalui instrumen penggunaan kekerasan, ancaman, monopoli, dan melalui korupsi oleh pejabat publik. Salah satu aspek penting dalam operasi kriminal transnasional adalah mengenai jaringan lintas batas negara tergolong fleksibel bersifat horizontal dengan tingkat hirarki minim. Sehingga berdasarkan laporan UNDOC (Van Dijk \& Spapens, 2014), secara struktural sebagian besar TOC berbentuk jaringan yang fleksibel tanpa adanya hirarki yang bersifat rigid. Selain itu lebih lanjut laporan tersebut menunjukan bahwa $70 \%$ dari kelompok kriminal beroperasi secara transnasional minimal di tiga negara. Kelompok kriminal seperti halnya mafia biasanya beroperasi di negara dengan tingkat otoritas lemah, tingkat korupsi tinggi, setrta angka penegakan hukum yang lemah, bahkan dalam beberapa hal kelompok kriminal justru menjadi sumber otoritas utama seiring lemahnya kemampuan perlindungan negara terhadap masyarakatnya.

Sejalan dengan pandangan diatas, decade 1990-an menjadi turning point aktivitas kriminal transnasional termasuk pasar ilegal dari permasalahan yang diabaikan menjadi dimensi ancaman keamanan global baru. Hingga saat ini aktivitas kelompok kriminal transnasional telah menjadi permasalahan besar dalam tata kelola baik pada level domestik ataupun tingkat global. Disisi lain pemerintah terbilang kesulitan dalam meredam aktivitas TOC dikarenakan kemampuan organisasi ini untuk secara terus menerus mengalami perkembangan dengan mereduksi kekuatan kemampuan tata kelola pemerintah. Berkaitan dengan kondisi tersebut, kehadiran TOC sebagai paradoks bahwa dalam perkembangan tata kelola global dewasa ini justru menyediakan kesempatan bagi mereka dalam memperoleh keuntungan dari kegiatan ilegal. Begitu juga dengan pembentukan rezim peraturan global 
pada akhirnya juga menyediakan celah bagi TOC untuk terlibat dan mengambil keuntungan dalam arus perkembangan ekonomi dan bisnis global yang mana justru merendahkan rezim dan aturan tersebut. Maka dari itu, respon terhadap TOC saat ini tidak dapat hanya melalui kesadaran negara serta tata kelola tradisonal secara bilateral (Williams, 2001). Berkaitan dengan aktivitas illicit trade sebagai bagian dari TOC, terdapat berbagai alasan dibalik massifnya perdagangan illegal; pertama, salah satu penyebab paling dasar adalah ketidakmampuan negara dalam menegakan aturan hukum. Kedua, sebagian besar perdagangan ilegal dilakukan lintas batas negara yang sebenarnya merefleksikan ketidakmampuan elemen internasional dalam memperkuat larangan dalam regulasi rezim perdagangan internasional. Ketiga, pra-kondisi ekonomi ilegal terakhir adalah adanya permintaan tinggi terhadap barang dan jasa ilegal dalam pasar internasional. Ketiga unsur penyebab umum tersebut terkorelasi satu sama lain bersamaan dengan unsur penyebab pendukung lain seperti kemiskinan dan perkembangan teknologi. Seiring perekonomian ilegal telah menjadi permasalahan kompleks, maka harus ditangani melalui kebijakan kompleks (Felbab-Brown, 2009). Felbab-Brown menyatakan bahwa penegakan aturan oleh negara dan aktor internasional tidak dapat hanya menyasar pada tindakan penegakan hukum yang menyasar pada sisi penawaran dari organisasi kriminal, akan tetapi juga harus menyasar pada sisi permintaan yang mana melemahkan keinginan konsumen barang ilegal melalui ancaman hukuman sosial dan psikologis (Felbab-Brown, 2009). Kehadiran TOC sebagai konsekuensi politik rasional terhadap pemerintahan domestik maupun internasional. Aspek tata kelola mengenai bagaimana ancaman aktivitas kriminal dapat diatasi namun pada satu sisi masih menjadi perdebatan dikalangan penstudi dan pembuat kebijakan (Edwards \& Gill, 2002). Setidaknya terdapat dua diskursus narasi yang saling kontradiktif terhadap permasalahan TOC yaitu pertama adalah pemahaman secara top-down yang mana kriminalitas transnasional merupakan ancaman negara, maka negara memiliki tanggung jawab terhadap penyusunan kebijakan penanganan. Semenatara disisi lain aktivitas kriminal merupakan realitas yang berada di masyarakat, sehingga perlu teknik tata kelola baru penanganan yang dimulai dari sektor kemasyarakatan (Edwards \& Gill, 2002).

\section{Ancaman Perburuan Gajah dan Perdagangan Gading llegal di Republik Demokratik Kongo}

Benua Afrika memiliki kekayaan ragam satwa liar terutama di sub-kawasan sahara atau Afrika bagian Tengah. Keanekaragaman menjadikan negara-negara kawasan menjadi rawan sebagai pusat dari aktivitas perburuan dan perdagangan satwa liar oleh jaringan organisasi kriminal internasional. Salah satu spesies satwa yang kerap diburu sebagai komoditas perdagangan ilegal adalah gajah Afrika. Pada tahun 2013 populasi gajah Afrika diprediksi berada pada kisaran 400-600 ribu ekor yang mana sebagian besar diantaranya berada di Afrika Tengah terutama di negara seperti Tanzania, Botswana, dan Zimbabwe. Jaringan sindikat kriminal melakukan perburuan terhadap gajah Afrika guna memanfaatkan gadingnya sebagai komoditas perdagangan bernilai tinggi. Berdasarkan laporan Reuters, di Cina sebagai salah tujuan utama ekspor gading ilegal, harga gading di "pasar gelap" relatif tinggi walaupun dalam beberapa tahun mengalami penurunan. Pada tahun 2014 harga gading berkisar pada 2100 USD per kilogram yang kemudian turun menjadi 1100 USD per kilogram dan berkisar pada 750 USD per kilogram pada tahun 2017 (Reuters, 2017). Ancaman kriminal transnasional terhadap populasi gajah Afrika pada dasarnya dapat dilihat dari dua indikator aktivitas yaitu perburuan gajah dan perdagangan gading sebagai komoditas ekonomi utama dari gajah. Terdapat trend kenaikan jumlah perburuan gajah Afrika yang terdeteksi baik di tiga sub-kawasan Afrika meliputi Afrika Tengah, Timur, dan Barat antara tahun 2010-2012. Apabila mengacu kembali pada data oleh UNODC peristiwa perburuan gajah tertinngi berada di negara-negara Afrika Tengah yang mana pada tahun 2010 tercatat perburuan gajah mencapai 7,8 ribu ekor kemudian meningkat menjadi 13,6 ribu ekor pada tahun 2011 dan 2012. Apabila jumlah ini dikalkulasikan dengan sub-region lainnya, pada tahun 2010 sebanyak 19 ribu gajah telah diburu dan lebih dari 35 ribu ekor gajah diburu pada tahun 2012 di seluruh negara Regional Afrika (United Nation On Drug and Crime, 2016). Berdasarkan data tersebut maka tidak dapat dipungkiri bahwa Kawasan Afrika Tengah merupakan sumber utama dibalik aktivitas perdagangan gelap gading gajah ke seluruh dunia. Tabel di bawah (Tabel 1.2) 
menunjukan bagaimana peredaran gading gajah mengalir dari wilayah sumber habitat gajah di Afrika lalu beredar menuju negara-negara tujuan hingga menuju dataran Eropa dan Asia. Dalam jangka waktu tahun 2009 hingga 2014, data CITES mencatat sebanyak 91 proses pengiriman lintas batas terdeteksi dengan muatan 159 metrik ton raw ivory atau setara dengan estimasi 15 ribu ekor gajah yang terbunuh. Jumlah tersebut sebagian besar ditemukan di wilayah timur Afrika sebagai central shipment arus perdagangan dari penyuplai barang di negara-negara Afrika Tengah. Sementara itu Cina menjadi destinasi utama pasar perdagangan gading di seluruh dunia dengan estimasi mencapai $42 \%$ yang kemudian diikuti dengan negara-negara Asia Tenggara dan Timur Tengah sebagai pengonsumsi utama komoditas raw ivory dari gajah-gajah di Afrika Tengah. Hal ini dibuktikan dengan jumlah penangkapan perdagangan ilegal gading terbesar terjadi di Cina yang mana mencapai keseluruhan 73 metrik ton pada tahun 2009-2014, berbanding dengan jumlah 66 metrik ton gading berhasil ditangkap di berbagai negara kawasan lain di luar Afrika dan Asia Tenggara dalam jangka waktu yang sama (CITES, 2015).

\section{Tabel 1.2}

\section{Persebaran Perdagangan Gading Gajah Ilegal}

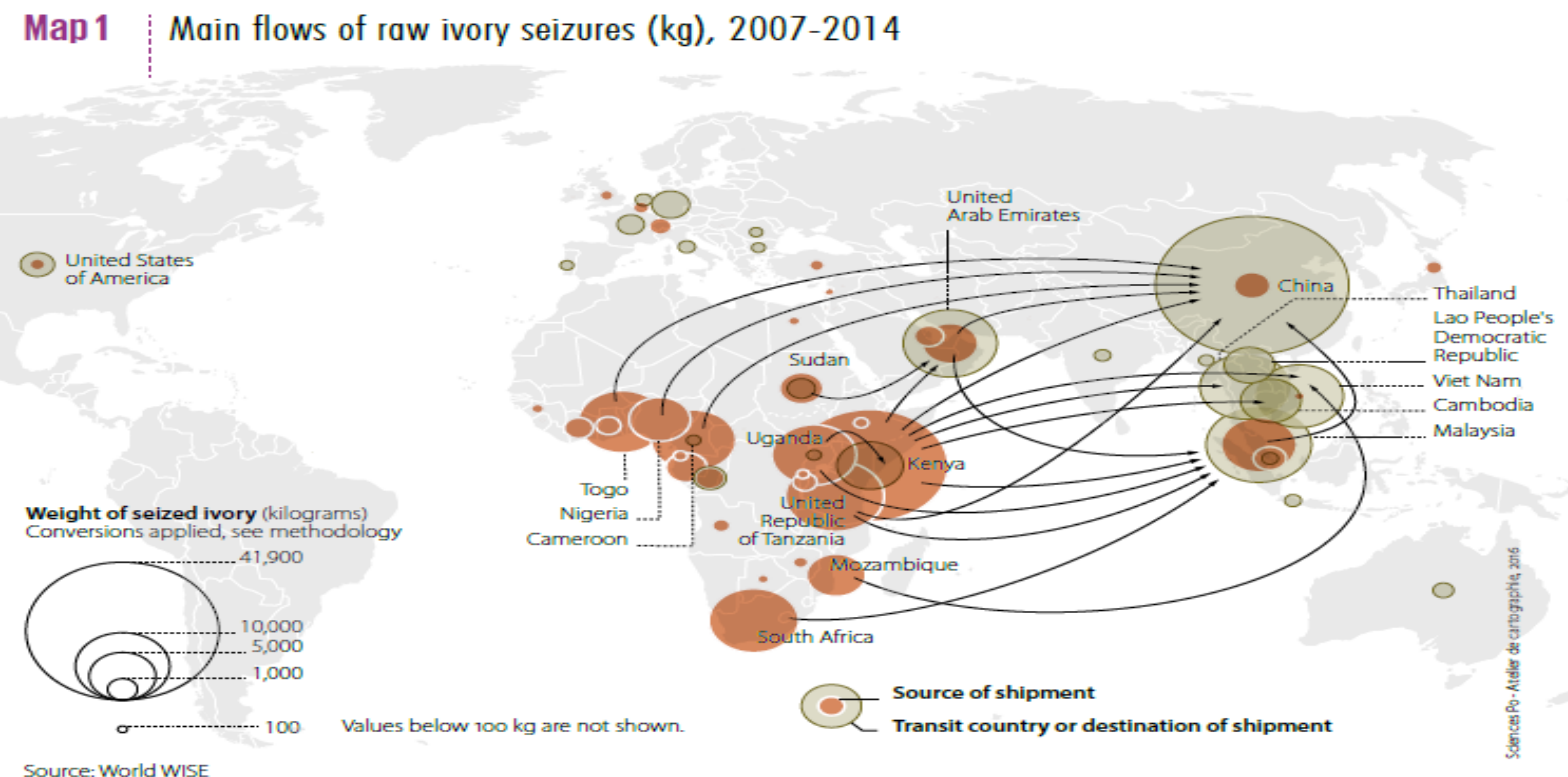

Sumber: www.unodc.org

Salah satu negara yang berada pada situasi darurat sebagai sumber aktivitas perburuan gajah serta perdagangan ilegal gading gajah Afrika adalah Republik Demokratik Kongo (DRC). Sebagai salah satu negara dengan wilayah terluas dimana $61 \%$ dari luas tersebut merupakan kawasan hutan tropis, negara ini merupakan rumah bagi gajah hutan di Afrika. Jenis gajah ini merupakan sub-spesies dari gajah Afrika yang berukuran lebih kecil dengan ukuran tengkorak, kuping, serta gading yang lebih lurus dari seluruh sub-spesies gajah Afrika. Laporan African Elephant Status Report pada tahun 2016 mengestimasikan terdapat sekitar 1800 ekor gajah hutan yang berada di wilayah kedaulatan DRC. Estimasi tersebut belum termasuk dengan prakiraaan jumlah tambahan yang belum terdata sejumlah 7,8 ribu hingga 9,5 ribu ekor gajah. Bermukimnya populasi gajah terutama dengan sub-spesies khusus, menjadikan negara ini sangat rentan terhadap adanya aktivitas wildlife crime berakibat pada semakin tereduksinya populasi dan keberagaman gajah di wilayah ini. Situasi ini terlihat dari bagaimana populasi gajah Hutan DRC menurut data oleh British Columbia University (Siyabona Africa, 2017) mengalami degradasi populasi secara masif sebesar $50 \%$ pada dekade 2000-an. Nilai tersebut salah satunya dapat dilihat di kawasan konservasi Okapi yang diperkirakan pada tahun 2011 populasi total berada pada kisaran 3,3 ribu ekor berbanding dengan estimasi 6,4 ribu ekor pada dekade sebelumnya. Situasi serupa juga terdata di bagian timur DRC yang merupakan salah satu hutan tropis terluas sekaligus pusat populasi gajah 
yang diperkirakan mengalami penurunan populasi drastis dari 22 ribu menjadi hanya tersisa sekitar enam ribu ekor gajah Hutan Afrika. Begitu juga survey di Taman Nasional Garamba terutama di bagian selatan terdapat penurunan estimasi populasi gajah dari 6,3 ke 4,1 ribu ekor pada tahun 2004 menjadi sekitar 1,7 ribu ekor gajah pada tahun 2014.

Perburuan dan perdagangan gading ilegal di DRC mulai terlihat secara masif bersamaan dengan terjadinya Perang Sudara di negara ini dari tahun 1996 hingga 2003. Perang berdampak besar bagi naiknya angka kejahatan terhadap gajah di DRC diakibatkan oleh dua hal. Pertama adalah situasi perang mengakibatkan lemahnya kemampuan perlindungan dan aktivitas konservasi pemerintah terhadap populasi gajah. Selain itu perang juga mengakibatkan pengabaian penegakan hukum bagi kejahatan satwa gajah di DRC. Kedua adalah adanya penguasaan wilayah konservasi oleh kelompok militer dan pengungsi yang kemudian mulai meningkatkan perburuan terhadap gajah dalam upaya memenuhi kebutuhan-masing-masing (Marpi \& Erlangga, 2021). Berakhirnya perang saudara justru tidak diikuti perubahan signifikan, perburuan gajah justru menjadi bagian dari aktivitas sehari-hari. Aktivitas ini dilakukan oleh sindikat TOC sebagian besar berasal dari rebel military group yang masih terafiliasi dengan kelompok militer bersenjata dan insurgen pada masa perang saudara salah satunya adalah Lord's Ressitance Army yang beroperasi hampir di seluruh negara di Afrika Tengah (C.R. Thouless et al., 2016). Ancaman ilegal poaching dan illicit wildlife trade bagi DRC terbilang sangat sulit diatasi bahkan masih berlangsung dalam intensitas tinggi dewasa ini. Kondisi memperihatinkan dapat dilihat dari banyaknya jumlah penangkapan raw ivory dari DRC menuju ke pasar ilegal terutama di negara-negara kawasan Asia Tenggara dan Cina. Salah satunya dilaporkan oleh berita African News pada Juli tahun 2019 bahwa Pemerintah Singapura melakukan penangkapan terhadap sindikat illicit ivory trade yang membawa 8,8 ton gading ilegal dari DRC menuju Vietnam. Sebelumnya pada tahun 2018 otoritas penerbangan DRC mendapati penyelundupan 62 kilogram gading di Bandara Kinshasa. Penyelundupan ini terkait dengan sindikat TOC dari Tanzania di Kinshasa, DRC, yang berusahan mengekspor barang ilegal tersebut menuju Malaysia (African News, 2019).

Peristiwa penangkapan diatas pada dasarnya hanya merupakan gambaran kecil dari keseluruhan situasi yang terjadi. Faktanya DRC telah menjadi salah satu pusat komoditas gading ilegal sekaligus penyalur menuju pasar global di berbagai negara. Hal ini dibuktikan data Traffic yang diterbitkan pada September 2017 menyebutkan bahwa wilayah Kinshasa di DRC merupakan pusat aktivitas perdagangan gading di seluruh dunia dengan persentasi $68 \%$ atau $2 / 3$ dari komoditas gading yang diperdagangkan pada pasar global. Berdasarkan keterangan yang diperoleh dari pusat perdagangan gading Bikeko di Kinshasa menjelaskan bahwa raw ivory hasil perburuan dari Timur DRC masuk ke Kinshasa lalu bergerak menuju wilayah lain baik dalam bentuk raw ivory atau komoditas olahan menuju Tanzania, Rwanda, Uganda, dan Burundi sebagai negara terdekat yang memiliki aturan hukum serta pengawasan perbatasan yang lemah. Sementara itu untuk transaksi ilegal menuju regional lain disebutkan bahwa perdagangan ilegal gading melibatkan perusahaan pengiriman dari Cina dengan dominasi konsumen pembeli berasal dari Cina, Prancis, Amerika Serikat, Pakistan, dan Vietnam (Christopher et al., 2017).

\section{Respon Global terhadap Permasalahan Wildlife Crime dan Ilegal Ivory Trade di Republik Demokratik Kongo (DRC)}

Aktivitas TOC dalam perburuan gajah dan perdagangan gading secara ilegal di DRC pada dasarnya dapat digolongkan sebagai permasalahan global seiring proses produksi, distribusi, dan konsumsi dalam bentuk jaringan yang terkoneksi lintas batas negara. Maka dari itu diperlukan jaringan respon global sebagai upaya mengatasi permasalahan atau setidaknya mempersempit ruang gerak bagi akibat aktivitas perburuan dan komersialisasi komoditas gajah di pasar ilegal. Dalam mengatasi tingginya angka perburuan gajah dan perdagangan gading, pada dasarnya pemerintah DRC telah mulai menggalakan aksi perlindungan keanekaragaman satwa terutama gajah sejak awal tahun 1990-an melalui realisasi program National Ivory Action Plan (NIAP) serta sejak dekade sebelumnya telah didukung dengan otoritas publik L'Institiute pour la Conservation de la Nature (ICCN) sebagai lembaga khusus proteksi lingkungan di DRC sejak tahun 1975. Akan tetapi implementasi program dan upaya konservasi oleh ICCN cenderung terhambat salah satunya diakibatkan oleh perang saudara 
yang terjadi sejak pertengahan dekade 1990-an. Peran ICCN dalam konservasi alam DRC termasuk perlawanan terhadap perburuan gajah terbilang sentral. Lembaga ini bertanggung jawab terhadap tata kelola delapan taman nasional atau menjangkau hingga $13,5 \%$ dari keseluruhan wilayah territorial DRC dengan tujuan utama konservasi alam serta perlindungan terhadap keanekaragaman satwa (Salonga National Park, 2019). Personel ICCN bersama tentara nasional menjadi gerbang awal perlawanan terhadap perburuan dan perdagangan gajah menghadapi jaringan sindikat militan pemburu gajah. Sebagai contoh aksi, pada tahun 2014 patroli yang dilakukan oleh jajaran ICCN mendapati sebanyak 68 gajah tewas diburu di Taman Nasional Garamba (African Parks, 2014).

Keseluruhan aksi perlindungan baik dalam kerangka ICCN dan upaya Pemerintah DRC lainnya berpusat pada implementasi strategi National Ivory Action Plan (NIAP) yang mulai diimplementasikan pada tahun 2015. Setidaknya terdapat enam fokus kebijakan penanganan perburuan dan perdagangan gading ilegal yang meliputi penguatan aturan hukum diantaranya melalui Law No.14/003 tahun 2014 tentang program konservasi dan Law No.82/002 tahun 1982 tentang regulasi perburuan satwa. Selain penguatan aturan langkah lain adalah dengan proses investigasi, sistem intelijen kawasan, koopreasi internasional, operasi represif sesuai regulasi, serta kegiatan peningkatan kesadaran masyarakat serta komunikasi antar instansi. Implementasi nyata NIAP kemudian diterapkan setiap tahunnya yang kemudian dilaporkan dan diawasi secara internasional melalui otoritas CITES (Minister of Environment and Sustainable Development Democratic Republic of Congo, 2015). Begitu juga dengan laporan NIAP oleh Pemerintah DRC tahun 2018-2019 juga memuat pilar strategi yang sama yaitu penguatan regulasi, langkah investigasi, intelijensi, aksi internasional, operasi represif, dan langkah preventif. Akan tetapi pada pelaksanaanya dilakukan berbagai revisi salah satunya mengenai revisi beberapa pasal dalam Law No.82/002 tahun 1982 tentang regulasi perburuan (CITES, 2017).

Implementasi strategi NIAP oleh Pemerintah DRC pada dasarnya merepresentasikan komitmen negara tersebut terhadap perbaikan tata kelola satwa liar terutama dalam mengatasi perburuan serta perdagangan gading ilegal dalam kerangka institusi internasional dan regional. Pada ranah regional wujud komitmen ini tertuang dalam berbagai kesepakatan diantaranya adalah pada ranah Economic Community on Central African States (ECCAS) yang mengembangkan rencana komisi koordinasi strategis pada tahun pada tahun 2012 (COMIFAC) dengan tujuan memperkuat regulasi dan aturan hukum oleh negara-negara subregional ini terhadap keanekaragaman satwa. Selain itu wujud komitmen regional lain adalah pengembangan langkah strategis perlindungan gajah dalam Southern African Development Community (SADC) (Minister of Environment and Sustainable Development Democratic Republic of Congo, 2015). Comission on Central African Forest (COMIFAC) merupakan kesepakatan delapan negara Afrika Tengah termasuk DRC dalam berupa jaringan langkah strategis menghadapi perburuan liar dan perdagangan satwa ilegal sejak tahun 2011. Kesepakatan ini memuat empat poin utama yaitu kolaborasi regulasi, kooridnasi batas teritori, penyelarasan kebijakan, serta peningkatan kesadaran terhadap permasalahan kriminal ini (Traffic, 2012). Sementara itu langkah regional lain yang diambil DRC bersama negara subkawasan lainnya dapat dilihat melalui serangkaian kesepakatan. Salah satunya adalah Africa Trade in Wildlife Information Exchange (Africa-TWIX) bersama Gabon, Kamerun, Kongo, dan Republik Afrika Tengah. Kesepakatan ini secara umum memuat sharing informasi dan pengembangan teknologi oleh lima negara tersebut dalam merespon perkembangan teknologi dalam perburuan gajah dan perdagangan gading oleh sindikat TOC (Christopher et al., 2016). Sementara itu dalam tingkat internasional wujud komitmen terhadap perbaikan ini sudah terlihat sejak tahun 2011 ketika Perdana Menteri DRC Adolphe Muzito dan Direktur Jenderal UNESCO menyepakati deklarasi Kinshasa yang memuat komitmen terhadap tindakan strategis perlindungan objek keanekaragaman satwa (UNESCO, 2011).

Selain melalui otoritas publik pada tingkatan regional dan internasional, respon terhadap perdagangan ilegal dan perburuan gajah liar di DRC ini juga dibangun atas langkah koordinasi dengan otoritas privat dan organisasi non-negara yang bergerak dalam bidang lingkungan dan satwa. Salah satunya adalah National Action Ivory Plan (NIAP) Pemerintah DRC merupakan realisasi kebijakan yang didasari oleh aturan dalam Convention on International Trade in Endangered Species of Wild Flora and Fauna (CITES). Konvensi ini 
bertindak sebagai otoritas privat yang memberikan dasar dan panduan bagi negara-negara dalam memperkuat aksinya melawan perdagangan satwa ilegal yang terealisasikan dalam bentuk NIAP (CITES, 2015). Berkaitan dengan arus perdagangan gading ilegal utamanya yang berasal dari DRC, implementasi NIAP oleh CITES juga mempengaruhi kepatuhan oleh negara-negara yang menjadi destinasi pasar. Salah satunya adalah Cina sebagai negara destinasi terbesar mulai tahun 2014 yang berakibat pada turunnya penangkapan disertai harga pasar gading yang jatuh drastis sejak larangan diberlakukan (Reuters, 2017).

Jaringan kebijakan perlawanan terhadap sindikat kejahatan terhadap gajah di DRC juga melibatkan organisasi internasional non-pemerintah yang bergerak dalam upaya perlindungan satwa. Salah satunya adalah WWF berfungsi sebagai elemen pendukung sekaligus pelaksana tindakan persuasif guna meningkatkan kesadaran dunia terhadap kriminalitas satwa yang terjadi. Fungsi serupa juga dilakukan oleh INGOs lainnya yatu TRAFFIC dalam mengawasi sekaligus mensuplai informasi terkait perkembangan situasi yang terjadi. Pada dasarnya segala rencana stratgis dalam NIAP oleh Pemerintah DRC bahkan hingga pelaksanaanya melibatkan elemen INGOs terutama WWF dan TRAFFIC. Sementara itu upaya lain juga dilakukan seperti WWF adalah dengan melahirkan WWF Africa Species Action Plan pada tahun 2007 yang menyasar negara-negara Afrika dengan memberikan rekomendasi kebijakan serta pelatihan penanganan kejahatan terhadap satwa. Upaya ini memiliki tujuan besar dalam konservasi populasi gajah dengan menghentikan segala aktivitas yang mengancam habitat gajah Afrika(WWF, 2007). Sementara itu kontribusi TRAFFIC secara konsisten juga terlihat melalui pemantauan pelaporan terhadap implementasi hukum dan kebijakan perlindungan satwa oleh negara. Sebagai contoh di DRC tahun 2015 TRAFFIC melaporkan bahwa penegasan aturan terkait larangan perburuan dan perdagangan gading kurang maksimal diiringi dengan manajmen penaganan minim, serta adanya korupsi dan keterlibatan oknum negara dalam proses perdagangan ilegal yang terjadi (EIA, 2020). Kontribusi organisasi masyarakat diatas pada dasarnya hanya sebagian kecil dari banyak keterlibatan organisasi lingkungan non-negara yang saling terkoneksi satu sama lain dalam isu ini seperti WCS, WISE, Greenpeace, banyak organisasi lain. Aksi tersebut belum termasuk perlawanan dari komunitas masyrakat local DRC yang juga memegang peranan penting dalam illegal poaching dan illegal ivory trade.

\section{KESIMPULAN}

Berdasarkan uraian diatas, penulis menarik kesimpulan bahwa perburuan gajah dan perdagangan gading gajah secara ilegal merupakan permasalahan global yang harus mulai mendapatkan urgensi perhatian dari elemen global. Hal ini dikarenakan perilaku kriminal tersebut dapat berdampak pada kerusakan ekosistem alam serta berkuranganya spesies satwa terutama gajah dalam jumlah yang masif. Salah satu negara yang berada dalam situasi darurat perburuan serta perdagangan ilegal satwa gajah adalah Republik Demokratik Kongo (DRC). Setiap tahunnya DRC merupakan destinasi utama aktivitas perburuan gajah oleh TOC dikarenakan tingginya tingkat populasi gajah Afrika terutama sub-spesies gajah hutan. Jumlah ini berbanding lurus dengan catatan perburuan terhadap spesies gajah tersebut yang relatif tinggi. Selain itu Kawasan Kinshasa juga dikenal sebagai pusat perdagangan produk gading gajah serta tenpat transit bagi arus perdagangan gading mentah menuju Afrika Timur lalu dipasarkan secara global. Masalah wildlife crime di DRC mulai mengalami peningkatan drastis pada periode perang sipil sejak tahun 1996. Pada masa tersebut perburuan dan perdagangan gajah marak dilakukan oleh kelompok militer insurgensi dan pengungsi terutama yang berada di wilayah timur. Sementara itu pasca perang aktivitas tersebut masih berlanjut dan justru melibatkan elemen aktor TOC dari negara lain seperti Sudan, Uganda, Kongo, dan Tanzania dikarenakan tingginya nilai gading gajah di pasar ilegal.

Situasi yang terjadi mulai mendapatkan perhatian pemerintah dan khalayak global terutama memasuki dekade 2010-an. Perhatian ini dapat dilihat melalui adanya respon perlawanan terhadap aktivitas TOC baik oleh Pemerintah DRC maupun jaringan kebijakan global. Dilihat dari sektor Pemerintah DRC, respon dilakukan dengan berbagai perbaikan aturan dan langkah strategis terhadap pelaku kriminal pemburu dan pedagang gading ilegal yang tersusun dalam rencana strategis nasional (NIAP). Upaya ini dilakukan sejak tahun 2015 dan melalui berbagai upaya revisi kebijakan setiap tahunnya. Kebijakan pemerintah tersebut 
pada dasarnya terkait dengan komitmen terhadap kesepakatan dalam kerangka aksi regional serta internasional yang berlaku baik berasal dari otoritas publik maupun otoritas privat. Upaya ini menghasilkan jaringan kebijakan yang melibatkan bukan hanya DRC sebagai negara produsen, melainkan dari negara konsumen, organisasi regional dan internasional, INGOs, bahkan terdapat peran oleh komunitas masyarakat lokal. Permasalahan perburuan gajah danperdagangan gading ilegal di DRC menurut penulis memberikan pembelajaran bahwa aktivitas TOC terutama wildlife crime dalam bentuk perburuan dan perdagangan satwa ilegal merupakan realitas permasalahan yang harus mendapatkan perhatian global. Dewasa ini globalisasi telah mengakibatkan aktivitas kejahatan serta kegiatan ilegal terkoneksi menjadi jaringan kejahatan lintas batas negara, maka dari itu respon tidak lagi dapat dilakukan secara unilateral. Akan tetapi harus berupa jaringan kebijakan yang idealnya melibatkan kontribusi dari otoritas tertinggi hingga elemen komunitas masyarakat terkecil sekalipun.

\section{DAFTAR PUSTAKA}

African News. (2019). Largest Ivory Haul from DR Congo Seized in Singapore. Https://Www.Africanews.Com/2019/07/23/Largest-Ivory-Haul-from-Dr-Congo-Seized-inSingapore/. https://www.africanews.com/2019/07/23/largest-ivory-haul-from-dr-congoseized-in-singapore/

African Parks. (2014). Poaching Onslaught in Garamba National Park. https://www.africanparks.org/newsroom/press-releases/poaching-onslaught-garambanational-park

Brecht, H. L. (2016). Use of Dichotomous Ivory Stockpile Management Strategies by African Elephant Range States: A Threat $t$ Effectively Combatting the Illegal Ivory Trade [Concordia https://digitalcommons.csp.edu/cgi/viewcontent.cgi?article=1026\&context=cup_common S_grad_ids

C.R. Thouless, H.T. Dublin, J.J. Blanc, D.P. Skinner, T.E. Daniel, R.D. Taylor, F. Maisels, H. L. Frederick, \& P. Bouché. (2016). African Elephant Status Report 2016. N.d. Central. https://portals.iucn.org/library/sites/library/files/documents/SSC-OP-060_A.pdf

Christopher, S. N., Chiambeng, P. N., \& Ahlers, N. (2016). WORKSHOP PROCEEDINGS: SUBREGIONAL ACTION PLANNING TO STRENGTHEN REGIONAL COLLABORATION Support of the Implementation of National Ivory Action Plans (NIAPS) in Central Africa . https://cites.org/sites/default/files/eng/prog/niaps/Kinshasa-NIAPWorkshop-Proceedings-May-2016.pdf

Christopher, S. N., Lagrot, J.-F., Ringuet, S., \& Milliken, T. (2017). IVORY MARKETS IN CENTRAL AFRICA. https://www.traffic.org/site/assets/files/1615/central-africa-ivoryreport-final.pdf

CITES. (2015). Introduction: Category C Parties https://cites.org/eng/prog/niaps/parties_of_importance_to_watch_introduction

CITES. (2017). National Ivory Action Plan of the Democratic Republic of the Congo 2018-2019. https://cites.org/sites/default/files/common/prog/niaps/DRC_Revised_NIAP_PostSC69_English translation.pdf

Edwards, A., \& Gill, P. (2002). The Politics of 'Transnational Organized Crime': Discourse, Reflexivity and the Narration of 'Threat.' The British Journal of Politics and International Relations, 4(2), 245-270. https://doi.org/10.1111/1467-856X.T01-1-00004

Ege, G., Schloenhardt, A., Schwarzenegger, C., \& Carl Grossmann Verlag. (2020). Wildlife Trafficking: the illicit trade in wildlife, animal parts, and derivatives Illegaler Handel mit Tieren, Tierbestandteilen und Tierprodukten. (D. Hürlimann \& M. Thommen (eds.); Vol. 9).

EIA. (2020). How West and Central Africa have become the epicentre of ivory and pangolin scale trafficking to Asia . https://eia-international.org/wp-content/uploads/Out-of-AfricaSINGLE-PAGES.pdf

Felbab-Brown, V. (2009). The Political Economy of Illegal Domains in India and China. Int'l Law., 43, 1411. http://www.nyimes.com/2009/08/2

Kideghesho, J. . (2016). The Elephant Poaching Crisis in Tanzania: A Need to Reverse the Trend and the Way Forward. Tropical Conservation Science, 9(1), 369-388. 
Marpi, Y., \& Erlangga. (2021). The Criticism of Social Justice in Economic Gap. Insignia: Journal of International Relations, 23-31. https://doi.org/https://doi.org/10.20884/1.ins.2021.0.0.3759

Minister of Environment and Sustainable Development Democratic Republic of Congo. (2015). National Action Plan of the DRC. https://cites.org/sites/default/files/common/prog/niaps/E-NIAP-DRC-2015-2016.pdf

Reuters. (2017). China ivory prices fall on ban, but illegal markets abroad thrive: researchers. https://www.reuters.com/article/us-africa-china-elephants-idUSKBN171101

Salonga National Park. (2019). ICCN-Conserving and Protecting Nature is Our Moral Duty. https://salonga.org/partners/iccn/

Siyabona Africa. (2017). War impacts elephant populations in eastern Congo. https://www.krugerpark.co.za/kruger-park-news-e-11-war-impacts-elephant-populationsin-eastern-congo-25413.html

Stephenson, P. J., \& Ntiamoa-Baidu, Y. (2020). Conservation planning for a widespread, threatened species: WWF and the African elephant Loxodonta africana. https://doi.org/10.1017/S0030605309990846

Traffic. (2012). Central African countries agree plan to improve law enforcement and combat poaching. https://www.traffic.org/news/central-african-countries-agree-plan-to-improvelaw-enforcement-and-combat-poaching/

UNESCO. (2011). Director-General and DRC Prime Minister sign Kinshasa Declaration to protect World Heritage sites in the Democratic Republic of the Congo. http://www.unesco.org/new/en/member-states/singleview/news/director_general_and_drc_prime_minister_sign_kinshasa_declar/

UNESCO Media Services. (2017). Director General and DRC Prime Minister sign Kinshasa Declaration to protect World Heritage sites in the Democratic Republic of the Congo I United Nations Educational, Scientific and Cultural Organization. http://www.unesco.org/new/en/media-services/singleview/news/director_general_and_drc_prime_minister_sign_kinshasa_declar/

United Nation On Drug and Crime. (2016). World Wildlife Crime Report. New York: UNODC. https://www.unodc.org/documents/data-andanalysis/wildlife/World_Wildlife_Crime_Report_2016_final.pdf

United Nations Office on Drugs and Crime. (2015). Wildlife crime worth USD 8-10 billion annually, ranking it alongside human trafficking, arms and drug dealing in terms of profits: UNODC chief. https://www.unodc.org/unodc/en/frontpage/2014/May/wildlife-crimeworth-8-10-billion-annually.html

Van Dijk, J., \& Spapens, T. (2014). Transnational organized crime networks. Handbook of Transnational Crime and Justice.

Williams, P. (2001). Crime, illicit markets, and money laundering. Managing Global Issues: Lessons Learned. https://carnegieendowment.org/pdf/files/mgi-ch3.pdf

WWF. (2007). WWF Species Action Plan: African Elephant 2007-2011. https://d2ouvy59p0dg6k.cloudfront.net/downloads/wwf_sap_african_elephants_final_jun e_2007v1_1.pdf 